\title{
Correct original spelling of Venanides caspicus (Hymenoptera: Braconidae)
}

\author{
Parisa ABDOLI ${ }^{1)}$, Ali Asghar TALEBI ${ }^{1)}$, Samira FARAHANI ${ }^{2)} \&$ Jose FERNANDEZ-TRIANA $^{3)}$ \\ ${ }^{1)}$ Department of Entomology, Faculty of Agriculture, Tarbiat Modares University, Tehran, Iran; \\ e-mail: p.abdoli@modares.ac.ir; talebia@modares.ac.ir \\ ${ }^{2)}$ Research Institute of Forests and Rangelands, Agricultural Research Education and Extension Organization (AREEO), Tehran, I. R. Iran; \\ e-mail: s.farahani@rifr-ac.ir \\ ${ }^{3)}$ Canadian National Collection of Insects, Ottawa, Canada; e-mail: Jose.Fernandez@agr.gc.ca
}

\author{
Accepted: \\ $5^{\text {th }}$ May 2020 \\ Published online: \\ $15^{\text {th }}$ May 2020
}

Abstract. Venanides caspicus Abdoli, Fernandez-Triana \& Talebi, 2019 (Hymenoptera:
Braconidae) is fixed as a correct original spelling following Article 24.2.3 of ICZN (1999).

Key words. Hymenoptera, Braconidae, correct original spelling, nomenclature

Zoobank: http://zoobank.org/urn:1sid:zoobank.org:pub:522FC340-1FF7-49DD-8672-BDA4B54C0B78

(C) 2020 The Authors. This work is licensed under the Creative Commons Attribution-NonCommercial-NoDerivs 3.0 Licence.

By mistake, the intended name Venanides caspicus Abdoli, Fernandez-Triana \& Talebi, 2019 was written within the text of the paper in two different variants: the intended one, $V$. caspicus (9-times throughout the text on the pages 543, 544, 545, 546, and 547), and incorrect V. caspius (lapsus calami, once in title on the page 543) (ABDoLI et al. 2019). Venanides caspicus Abdoli, Fernandez-Triana \& Talebi, 2019 is the correct original spelling of the name, while V. caspius must be considered as an incorrect original spelling and an unavailable name in zoological nomenclature (see Article 24.2.3, ICZN 1999).

\section{References}

ABDOLI P., TALEBI A. A., FARAHANI S. \& FERNANDEZ-TRIANA J. 2019: Venanides caspius sp. nov. from Iran, the first species of Venanides (Hymenoptera: Braconidae) described from the Palaearctic Region. Acta Entomologica Musei Nationalis Pragae 59 (2): 543-548. ICZN 1999: International Code of Zoological Nomenclature. Fourth edition. International Trust for Zoological Nomenclature, London, $306 \mathrm{pp}$. 